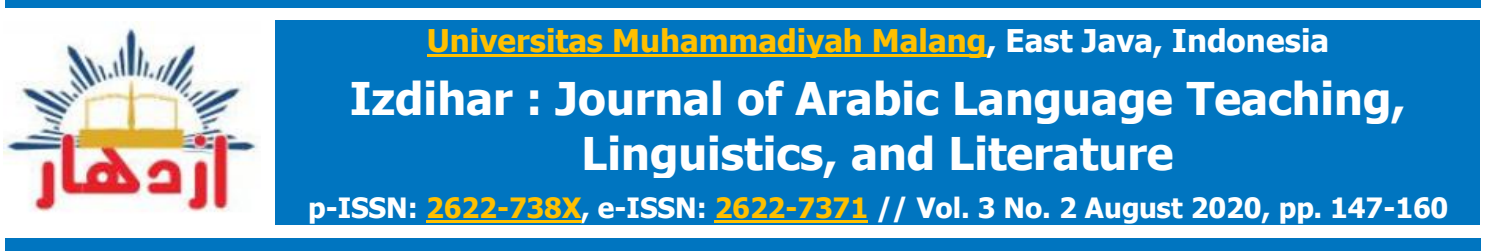

d.

https://doi.org/10.22219/jiz.v3i2.12514 http://ejournal.umm.ac.id/index.php/izdihar/index

\title{
The Influence of Using Audio-lingual Method on Students' Speaking Skill in Madrasah Diniyah Takmiliyah Awwaliyyah
}

\author{
Aprianto Aprianto ${ }^{a}, 1$, Mahyudin Ritonga ${ }^{b, 2}$, Yoni Marliusc, ${ }^{\text {, }}$, Raihan Nusyurd,4 \\ $a, b, c$ Muhammadiyah University of West Sumatera, Indonesia \\ dMarmara Üniversitesi, Turkey \\ 1afri6615@gmail.com, ${ }^{2}$ mahyudinritonga@gmail.com*3 ${ }^{3}$ yonimarlius@gmail.com, ${ }^{4}$ raihannusyur93@gmail.com
}

\section{ARTICLE INFO}

\section{Article History:}

Submitted: $15 / 06 / 2020$

Revised: $29 / 07 / 2020$

Accepted: 24/08/2020

Published: $31 / 08 / 2020$

\section{*Corresponding}

Author:

Name: Mahyudin

Ritonga

Email:

mahyudinritonga@gmail.com

\section{Keyword}

\section{ABSTRACT}

The study aimed to determine the influence of audio-lingual methods towards the Arabic speaking skills, the method used in this research was quantitative with experimental quasi approach, data collection technique was polling and test. The population of this research was 102 students in the MDTA Bustanul Huda at Padang City, West Sumatera, Indonesia. Data obtained through polls and tests were then analyzed statistically. The analysis used the normality test, homogeneity test, and hypothesis test. All three types of tests were done with the help of the SPSS Statistics 22 program. The results of the study were: 1 ) the use of audio-lingual methods was categorized on good classification with an average of 63.33 in intervals 62-64;2) Speaking Arabic skills was categorized on good classification with an average of 68 in intervals 65-68; and 3) the score of influence with N 30 obtained sig $a 0.001$ and the score of $r$ Square 0.35 . There was a significant influence between the use of audiolingual methods to the Arabic speaking skill of students at MDTA Bustanul Huda Ulak Karang at Padang City Indonesia in the academic year 2019/2020. The influence of variable $X$ to variable $Y$ because students are accustomed to hearing how to speak Arabic as the native speaker of the Arabic language.

Copyright (c) 2020, Aprianto et al

This is an open access article under the CC-BY-SA license

Arabic Language; Learning; Speaking Skill

\section{مستخلص البحث}

هذه الدراسة تهدف إلى معرفة تأثير استعمال طريقة السمعية الشفهية إلى ترقية مهارة الكلام لدى الطلاب، وكانت الطريقة

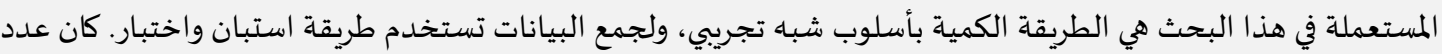

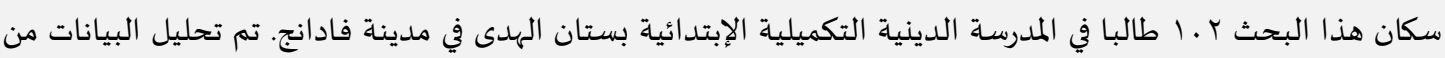

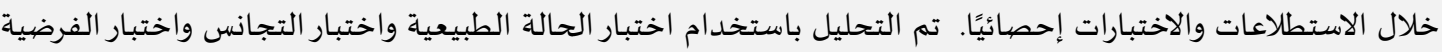

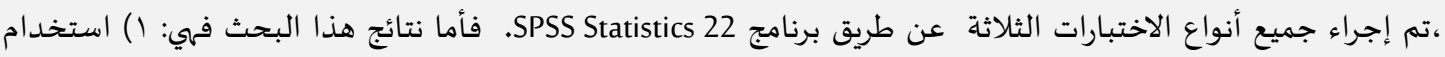

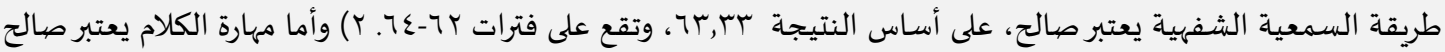

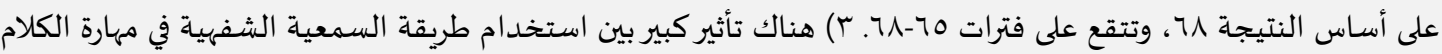
من نتائج الحساب ينظر 


\section{INTRODUCTION}

Learning Arabic in many aspects and at every grade of education to date still has a variety of problems. Problem occurs in aspects related to education and aspects related to the Arabic language itself. As it is known that the problems related to education in Arabic language learning are from the aspects of curriculum, materials, learning media, and learning methods.

The Arabic language is not the native language for students in Indonesia. Meanwhile, there are internal aspects of the Arabic language that differ from other languages such as phonetic of the Arabic language, the sound of Arabic which has a different nature and demands the way of pronunciation, even the difference of sound in Arabic (Rozi, 2017) is not available in Indonesian language (Nikmah, 2020), such as sound " $\dot{\varepsilon}$ " not found in Indonesia language. Similarly, the Sharaf aspect has some Wazans (Ritonga, Alrasi \& Bambang, 2018). Some patterns are not available in Indonesia language and there is a variety of other Arabic language internal aspects.

To solve the difficulties of learning the Arabic language, the Arabic observers and practitioners have also sought to seek solutions both through field research related to learning and research in the field of Arabic linguistics. In the field of education, many observers and practitioners of the Arabic language education conducted researches on methods of language learning, because the method is considered as one element of learning that affects the outcome of learning (Samah, Puteh-behak, Saad, Ali, Darmi, and Harun, 2016; Zahro, Amalia \& Amin, 2020).

Meyad, Roslan, Abdullah, and HajiMaming (2014) did experiments on the use of learning methods. The results of their research proved the difference of learning results of Arabic language between control class and experimental class. Samah et al (2016) also conducted research or learning methods and concluded that different methods used in the same learners produced a different quality of learning.

Janah and Nashoih (2019) also conducted an assessment of the effectiveness of a method on increasing learning outcomes. In this case, the method of learning is Intiqaiyah method. While other researches on cooparative learning as a learning strategy also concluded that the strategy could be recommended as an alternative to teaching Arabic for speakers outside of Arabic (Rachmawati, Nugrahaeni, Mauludiyah, 2020; Mei, Ju, Mohd, 2017).

In line with the research of observers and practitioners in the Arabic language learning method, one of the methods seen as a postmodern method (Wahab, 2015) is an audio visual method and audio-lingual method. While other researchers examine on audio visual methods concluded the audio method of 
visual effect on listening skills among learners (Rahmawati, 2019). While Maspalah (2015) who conducts research on the use of the audio-lingual method also concluded that the method enhances the results of Arabic language learning.

Hasyim (2015) conducted research on audio-lingual method in kalam learning revealed that the audio-lingual method was adapted to the habits experienced by students. The audio-lingual method is as one of the methods to achieve the purpose of learning as the plan of Ki Hajar Dewantara (Hanani, 2018). As a method that is deemed appropriate in teaching language skills, the method of Audio-lingual is not only used in teaching Arabic, but also the learning of any language this method has always been the choice (Bidenko \& Bespalova, 2017).

It is said because the audio-lingual method has the specificity of use and its application-oriented measures of speaking skill. The skill to speak as one of the four skills to be accomplished by language learners is often hindered by its achievement due to mistakes in selecting methods. The selection of audio-lingual methods for Arabic language learning is considered appropriate because of the condition of students in Indonesia who are not familiar with Arabic pronunciation.

In accordance with the initial observation that researchers did to Arabic learning process at Madrasah Diniyah Takmiliyah Awwaliyah (MDTA), students do not have the skill to reveal Arabic, on the other hand the method used by the teacher was limited to traditional methods as well as the appropriate instruction contained in the learning resources. Therefore, researchers offered the use of audio-lingual methods to teachers to change the habit of learners who are not accustomed to speak Arabic into habits in the learning process.

Audio-lingual is a way of teaching by giving exercises to what students have learned to acquire a certain skill (Hermawan, 2011). The word practice means that something is always repeated, but in any case, between the first learning situation and the realistic learning situation, it will try to practice students' skills. If the learning situation personalized the condition so as to demand a changing response, the skills will be more refined. From the above explanation, the audio-lingual method can be deemed appropriate to teach Arabic speaking skills. Speaking is one of the most complex and complicated language skills, complex and complicated because speaking takes some requirements of the linguistic that must be considered by the speaker. When students can master the terms of this linguistic, the student can be said to have speaking skills.

To improve the skill of learners in speech is not detached from the use of methods (Taufiq, 2018). The use of audio-lingual methods of language learning as expressed by Effendy will influence students' skill to recite letters, increase the skill to create sentence patterns, improve student speech, and the environment of the class will live because students are active in responding to learning materials (Effendy, 2009). Effendy's statement also corresponded to the research 
of Maspalah (2015) which conducted class action research on the XI MIA-2 class by applying the Audio-lingual method, from the results of the research, it can be concluded that the audio-lingual method affected the students' speaking skill.

Researchers examined some previous works and proposed an appropriate method for the influence of using audio-lingual methods to the students' speaking skill. Therefore, the most important advantage of this method was that it can perform very well the problem especially in aspects: first, the intensity of use of the audio-lingual method in MDTA, secondly, describing students' skills in speaking Arabic, third, reveals the effect of using the audio-lingual method towards the Arabic speaking skills.

\section{METHOD}

The study was designed using a quantitative approach. This method was selected to know the influence of the variable $X$ in this case the intensity of using audio-lingual method and $Y$ variable in the study of the direction of speaking skill. The selection of the method because it corresponded to the research material that is numeric.

The population of this research was 102 students in MDTA Bustanul Huda at Padang City, West Sumatera Indonesia. To facilitate researchers in conducting research, samples should have criteria in understanding the instructions made in the poll grid and the samples can read Arabic. Researchers set samples 30 (thirty) students from population. It means 29.4 percent from population. The samples were taken purposively among the population that met the criteria.

The instruments used in this study were a poll and a test. First, the usage a poll was to find out data related to variable $X$, the poll mentioned here was a statement that every informant can fill it without having to feel burdened. The arranged instruments were validated by two experts in the field of Arabic Education. After the validation of two experts, the instrument was used to know its conformity with the informant and research variables. The instruments were arranged preceded by a brief introduction, then there was a hint of how to fill it. The term used certainly did not contain two or more meanings. Statements were made short and dense. Each statement only contained a problem. The item of statement was ensured not to leaded by the desire of researchers. The alternative answer given in this poll is the Likert scale with categories 5: Very Good, 4: Good, 3: Good Enough, 2: Less Good, 1: Not Good. The summation of the poll results is then converted to: 
Table 1. The Summation Categorization of Variable $X$

\begin{tabular}{cc}
\hline Interval & Category \\
\hline $65-67$ & Very Good \\
\hline $62-64$ & Good \\
\hline $59-61$ & Good Enough \\
\hline $56-58$ & Less Good \\
\hline $53-55$ & Not Good \\
\hline
\end{tabular}

The Table 1 is a categorization of research data based on its interval. The basis of the interval setting was in accordance with the amount of the number of poll items contained in the poll grid.

The second instrument was a test. Test conducted to know the data related to the speaking skills (variables). The test material related to the skill of speaking Arabic and also the material that students have studied at MDTA Bustanul Huda. In the implementation, researchers were assisted with assessment instruments in the form of categorization by the likert scale with categories 5: Very Good, 4: Good, 3: Good Enough, 2: Less Good, 1: Not Good. The summation of the test result recapitulation was converted as in Table 2.

Table 2. The Summation Categorization of Variable $\mathbf{Y}$

\begin{tabular}{cc}
\hline Category & Conversion \\
\hline $73-76$ & Very Good \\
\hline $69-72$ & Good \\
\hline $65-68$ & Good Enough \\
\hline $61-64$ & Less Good \\
\hline $57-60$ & Not Good
\end{tabular}

The Table 2 was a categorization of variable $Y$ research data based on its interval. The interval assignment was based on the highest score earned by the student who then adjusted to the category set in MDTA.

The research was conducted for three months, September - November 2019. The data obtained through polls and tests were analyzed statistically to observe the influence audio-lingual method. Then, the analysis used the normality test, homogeneity test, and hypothesis test. All three types of test was done with the help of SPSS Statistics 22 program.

Based on the explanation in the introduction and description of the research methodology, the authors could apply the hypothesis that was tested by this research. $\mathrm{H}_{0}$ was the use of the audio-lingual method did not influence students' speaking skill in Arabic language. Ha was the use of the audio-lingual method influenced students' speaking skill in Arabic language. 


\section{RESULTS \& DISCUSSION}

In accordance with the data obtained through the distribution of the poll, the data related to the intensity of the use of audio-lingual method (variable $X$ ) in MDTA Bustanul Huda was explained in Table 3.

\section{Table 3. Frequency Distribution of Using Audio-lingual Methods Classification Frequency Percentage}

(\%)

\begin{tabular}{ccc}
\hline Very Good & 2 & 6.66 \\
\hline Good & 9 & 30 \\
\hline Good Enough & 8 & 26.66 \\
\hline Less Good & 6 & 20 \\
\hline Not Good & 5 & 16.66 \\
\hline Total & 30 & 100
\end{tabular}

Table 3 can be explained that the students who chose an overview of the usage intensity of audio-lingual method with a very good classification were 2 students (6.66\%), a good classification were 9 students (30\%), the classification was quite good amounting to 8 students $(26.66 \%)$, the classification was less good numbering 6 students (20\%) and who chose not good classification were 5 students $(16.6 \%)$.

Table 4. Frequency Distribution of Students' Speaking Skill

\begin{tabular}{cccc}
\hline Classification & Interval & Frequency & $\begin{array}{c}\text { Percentage } \\
\mathbf{( \% )}\end{array}$ \\
\hline Very Good & $73-76$ & 5 & 16,66 \\
\hline Good & $69-72$ & 12 & 40 \\
\hline Good Enough & $65-68$ & 8 & 26,66 \\
\hline Less Good & $61-64$ & 3 & 10 \\
\hline Not Good & $57-60$ & 2 & 6.66 \\
\hline Total & & $\mathbf{3 0}$ & $\mathbf{1 0 0}$
\end{tabular}

Furthermore, in accordance with the test results toward the Arabic speaking skills as in Table 4 can be interpreted that the Arabic speaking skills of students with a very good classification was 5 students $(16.66 \%)$, the classification with good numbered 12 students ( $40 \%)$, the classification with good enough was 8 students $(26.66 \%)$, the classification with less good was 3 students $(10 \%)$, and the classification with not good was 2 students $(6.66 \%)$. When the total score was done, an average score obtained 68 . It was categorized good enough.

Data variable $X$ and variable $Y$ as shown in Table 3 and Table 4, when test normality was performed, can be described as in Table 5 . 
Table 5. Normality Test Result

ANOVA $^{\text {a }}$

\begin{tabular}{llrrrrr}
\hline \multicolumn{2}{l}{ Model } & $\begin{array}{l}\text { Sum of } \\
\text { Squares }\end{array}$ & Df & \multicolumn{1}{c}{$\begin{array}{c}\text { Mean } \\
\text { Square }\end{array}$} & F & \multicolumn{1}{l}{ Sig. } \\
\hline 1 & Regression & 218.692 & 1 & 218.692 & 15.172 & $.001^{\text {b }}$ \\
\cline { 2 - 7 } & Residual & 403.608 & 29 & 14.415 & & \\
\cline { 2 - 7 } & Total & 622.300 & 30 & & & \\
\hline
\end{tabular}

a. Dependent Variable: Speaking Skills

b. Predictors: (Constant), Audio-lingual Method

According to the use of SPSS program with $\mathrm{N} 30$ from Table 5, the result obtained the price of $\operatorname{sig} a 0.001$. If the score of $\operatorname{sig} a$ obtained larger than 0.05 , the data obtained is not the normal distribution and if the score of sig a smaller than 0.05 , the data obtained normally. From the known results obtained the score of sig a 0.001 , the price of sig a 0.001 meant smaller than 0.05 , because the sig $a$ is smaller than 0.05 , the data was normal category. Then, researchers also test the homogeneity of the data acquisition. the test results of this homogeneity was explained in Table 6.

Table 6. Results of Homogeneity Test ANOVA

Speaking Skill

\begin{tabular}{llllcl} 
& Sum of & \multicolumn{3}{c}{ Mean } & \\
& Squares & Df & Square & $F$ & Sig. \\
Between Groups & 327.300 & 13 & 27.275 & 1.572 & .192 \\
Within Groups & 295.000 & 17 & 17.353 & & \\
Total & 622.300 & 30 & & &
\end{tabular}

By using SPSS program, the amount of $\mathrm{N} 30$ from Table 6 can be obtained the score of sig $a 0.192$. If the price of sig $a$ obtained more than 0.05 then the data obtained homogeneous and if the score of sig a smaller than 0.05 means the data obtained is not homogeneous. From the known results of the score of sig $a 0.192$, the price of sig $a 0.192$ meant larger than 0.05 , because sig a was larger than 0.05 then the data was homogeneous category.

To determine the influence significance of the use audio-lingual method against the Arabic speaking skill of students, the hypothesis test was conducted using SPSS Statistics 22 program. From the results of the calculation with N 30 obtained the score of sig $a 0.001$. If the score of sig a obtained larger than 0.05 , there is no influence of the use audio-lingual method to the Arabic speaking skill of students in MDTA Bustanul Huda Padang City, and conversely if sig $a$ is smaller than 0.05 , there is an influence of the use audio-lingual method against the Arabic speaking skill of students in MDTA Bustanul Huda Padang City. Based on hypothesis test, sig $a 0.001$ is smaller than 0.05 . it can be concluded that $\mathrm{H}_{\mathrm{a}}$ is accepted. 
The audio-lingual method is widely used by language teachers including Arabic language teacher. In this method, practices and exercises emphasized more in speaking, in the form of dialogue, preach, and so forth which students are expected to speak as native language (Mart, 2018).

The audio-lingual method as part of the development of the direct method was felt to have a weakness especially in explaining the things that students elusive (Sbai \& Ouakrime, 2016). For this method, besides emphasizing language teaching through listening and impersonating (Maaliah, Widodo \& Aziz, 2016), it is also possible to use mother tongue for explanation (Abu-Melhim, 2009). This method was usually more widely applied with the pattern drill form (Y. Mei, 2018). The use of drill approaches has been commonly used in military circles (Mart, 2018).

The inception of the audio-lingual method was the result of three historical circumstances. First, the emergence of linguistic figures that gave great attention to the observation and development of oral language (oral language learning). Such as Leonard Bloomfield, a 20th-century language scientist from America, documented native language conversational languages in America. Secondly, the emergence of psychological behaviorism that believed that all human behavior (including language) is taught through repetition and is influenced by the strengthening of the learning of both positive and negative strengthening. Thirdly, the outbreak of World War II, at which time the Americans recruited a lot of soldiers for military purposes all over the world. For this purpose, eventually the new soldiers were given training to qualify for the minimum proficiency in the military, one of which is the minimal skill of verbal communication, from this short course emerging methodology of language teaching through observation and repetition. This military-style teaching methodology was the forerunner of the next audio-lingual method development (Abu-Melhim, 2009).

In implementing this method, the Arabic teacher at MDTA performed the following steps: First, explaining the purpose and objectives of the guided exercise for the student; second, teacher emphasized on diagnosis, because the initial exercises cannot expect the students to gain the perfect skills; third, conducting guided exercises that arise different student responses to improve skills and refinement of students; fourth, giving time to hold a short exercise so as not to tiring and boring and the teacher needed to pay attention to the student's response whether to exercise properly and quickly; fifth, observing the obstacles or tribulations experienced by students by asking students, and observing the training period by changing the situation so as to give a rise to optimism and a sense of joy in the students who can produce good skills; sixth, teachers and students alike strive to realize the skill to speak. Seventh, teachers needed to pay attention to individual student differences, so that the abilities and needs of each student can thrive.

Based on the data findings, the use of audio-lingual method was done in MDTA Bustanul Huda in accordance with those expressed by the previous experts and researchers, as Larseen said that in the audio-lingual method is done first with the purpose of the training guided. Then, it is needed diagnosis because the 
beginner students cannot be expected to speak the language taught (Bidenko \& Bespalova, 2017). The provision of guided exercises to realize responses and give time to students was also delivered by Bidenko as in the results of his research (Ramadhan, 2017).

Furthermore, in the audio-lingual method attempted to manifest the skills not only arise from the teacher, but also from within the students, this is affirmed by the Maaliah et al. (2016) which confirmed that by using the audio-lingual method, the student's motivation in learning Arabic language is increasing, while Mart (2018) also concluded the use of audio-lingual methods made it easy for learners to achieve language skills. Observing the obstacles and difficulties faced by the students using the audio-lingual method should also be done by the language teachers (Ramadhah et al., 2018) this was needed because every student has a difference both from skill and motivation to learn Arabic.

The audio-lingual method as expressed by Hermawan (2011) that the audio-lingual method has some advantages, such as the students more freely to do the exercises, students are ready to use their skills because already familiarize, students have a good pronunciation, learners can be able to communicate orally well because of intensive listening and speaking exercises, the atmosphere of life class because the students are invited to be active in the learning activities.

Meanwhile, associated with the speaking skills described by Thu'aimah (2004) is one of the language skills that should be possessed by people who learn Arabic, while Syakur (2010) confirmed that every communicative approach is oriented towards language learning that embodies communicative competence in learners. Iskandarwassid and Sunendar (2009) revealed the strategies that can be done in learning the speaking skills are by choosing the right method, because the speaking skill aimed to familiarize students with speaking, clarify the articulation of learners in language, create learners who are responsible for what they are talking about, form critical hearing and establishing language usage habits.

The speaking skill can be measured from how learners pronounce letters, ways of speaking, use of language according to context (Pace, 1972). Speaking skills as taught in MDTA Bustanul Huda and how to teach it also looks appropriate to those expressed by Thu'aimah (2004), Syakur (2010), and Iskandarwassid (2009). This conformity indicated that the learning of Arabic language skills at MDTA Bustanul Huda aimed to familiarize students with the use of Arabic language and to realize their articulation clarity in revealing Arabic letters that correspond to the nature, mad, qashar, and makharij al-huruf.

The above exposure emphasized that learning the Arabic speaking skill requires the proper use of learning methods, even taking into consideration the situation and learning time for teachers should also be able to use the right media (Pace, 1972; Wargadinata, Maimunah, Febriani, \& Humaira, 2020; Susanti, Ritonga, \& Bambang, 2020; Sartika \& Ritonga, 2020), thus, the use of audiolingual method as done in MDTA Bustanul Huda can be seen to affect students' speaking skill.

Based on the discussion related to the audio-lingual methods and Arabic speaking skills, the data products the calculations against the quantitative data 
associated with the use of audio-lingual methods (variable $X$ ) have a significant influence on the skills of speaking Arabic students $(Y)$ in MDTA Bustanul Huda Padang City. Thus the zero hypothesis $\left(\mathrm{H}_{0}\right)$ in this study which reads "There is no influence from use of audio-lingual methods against the skills of speaking Arabic students in MDTA Bustanul Huda Padang City, this meant $\mathrm{H}_{\mathrm{o}}$ is rejected.

Therefore, this research can be said that the audio-lingual method affected the direction of students in MDTA Bustanul Huda Padang City. From the points of discussion, the authors can conclude that the use of the audio-lingual method was quite helpful. Therefore, an educator should have a high skill to guide and direct learners in terms of knowledge about the inside and practice in everyday deed and give examples as a figure that deserved to be imitated personality in community life especially towards learners. It is also very influential in the learning outcomes of the participants.

Statement $\mathrm{H}_{0}$ rejected was seen from the classification in variable $\mathrm{X}$, which was very good for 2 students (6.66\%), a classification of good by 9 students $(30 \%)$, the classification of quite good by 8 students $(26.66 \%)$, the classification of less good amounted to 6 students (20\%) And who chose an not good classification by 5 students (16.6\%).

Similarly, the classification is found in the direction of students (variable $Y$ ) with a very good classification of 5 students (16.66\%), a classification of good by 12 students ( $40 \%)$, the classification is quite good amounted to 8 students $(26.66 \%)$, the classification is less good by 3 students $(10 \%)$, and the classification is not good by 2 students $(6.66 \%)$. When the total score was done, the average score obtained 68 . From variable $X$ and $Y$ data, there were influences between the use of audio-lingual methods and Arabic speaking skills of students at MDTA Bustanul Huda Padang City for academic year 2019/2020.

The data meant that the audio-lingual method was appropriate to be used in improving speaking skills. It was not limited to learning Arabic speaking skills but for all languages in the world. This result was not independent of the various arguments of experts and observers related to the audio-lingual methods and the speaking skill as described and discussed. this result was also based on the basic functions of language as a means of communication.

\section{CONCLUSIONS}

Based on the results of the research and its discussion, the conclusions were: first, the use of the audio-lingual method in MDTA was classified as a good classification. Secondly, the Arabic speaking skills of students at MDTA Bustanul Huda also belonged to a good classification, after the addition of the score obtained an average 68 . This score can be categorized on a classification of both 
ranges at intervals of 65-68. The acquisition of data in variables $X$ and $Y$ indicated that there was a significant influence between the use of the audio-lingual method $(X)$ and the direction of the Arabic speaking skill of students $(Y)$ in MDTA Bustanul Huda of Padang City. From the result of the calculation seen in terms of influence with $\mathrm{N} 30$ obtained the score of sig a 0.001. It meant that the sig $a$ was smaller than 0.05 . Then there was an influence between the audio-lingual method of the Arabic speaking skill of students. It meant $\mathrm{H}_{0}$ was rejected and $\mathrm{H}_{a}$ was accepted. Researchers were aware that many language skills are influenced by a variety of factors. Therefore, other factors that affect the improvement of speaking skills need to be conducted advanced research both by their own researchers as well as other researchers and practitioners and observers of Arabic language learning. Furthermore research and discussion related to audio-lingual as it has done also needed research on this method by connecting it with variables other than speaking skills, or there are other researchers want to reexamine about the audio-lingual method and its correlates with Arabic speaking skills still open widely, as the research is limited by the space, time and skill of researchers. Likewise, the nature of social research whose justification is not absolute.

\section{ACKNOWLEDGMENT}

We thank to all people that have contributed to this research until we can finish it. We thank to all people in MDTA Bustanul Huda Padang City and Arabic Education Department in Muhammadiyah University of West Sumatera, Indonesia

\section{BIBLIOGRAPHY}

Abu-Melhim, A.-R. (2009). Re-evaluating the Effectiveness of the Audio-lingual Method in Teaching English to Speakers of Other Languages. International Forum of Teaching and Studies, 5(2), 39-45. ISSN:1555-872X

Bidenko, L., \& Bespalova, G. (2017). Implementing Audio-Lingual Method to Teaching Ukrainian AS A Foreign Language At The Initial Stage. Advanced Education, 7, 23-27. DOI: https://doi.org/10.20535/2410-8286.82711

Effendy, A. F. (2009). Metodologi Pengajaran Bahasa Arab. Bandung:Misykat.

Hanani, N. (2018). al-Thariqah al-Sam'iyyah al-Syafahiyyah fi Ta'lim al-Lughah al-'Arabiyyah wa Tatbiquha. Asalibuna, 2(2), 1-13. DOI:

https://doi.org/10.30762/asa.v2i2.1132

Hasyim, S. (2015). al-Thariqah al-sam'iyyah al-Syafahiyyah wa Tathbiquha 'ala Tadris al-Kalam. Lisanuna, 4(2), 236-250. DOI: 


\section{https://doi.org/10.30762/asa.v2i2.1132}

Hermawan, A. (2011). Metodologi Pembelajaran Bahasa Arab (Issue 1). Bandung: PT Remaja Rosda Karya.

Iskandarwassid, \& Suhendra, D. (2009). Strategi Pembelajaran Bahasa (Issue 2). Bandung: PT Remaja Rosda Karya.

Janah, M., \& Nashoih, A. K. (2019). Effectiveness of Al-Thariqah Al-Intiqaiyyah in Improving Arabic Learning Outcomes for Islamic Senior High School Students. Izdihar: Journal of Arabic Language Teaching, Linguistics, and Literature, 2(3), 201-216. DOI: https://doi.org/10.22219/jiz.v2i3.10108

Maaliah, E., Widodo, Y. H., \& Aziz, M. (2016). Using Audio-Lingual Method to Improve the Student's Speaking Skill (A Classroom Actian Research at the Fifth Grade of Madigondo Elementary School in the Academic Year of 2015/2016). Jurnal Bahasa Inggris Terapan, 3(1), 45-59.DOI: https://doi.org/10.35313/inggris.v3i1

Mart, C. T. (2018). The Audio-Lingual Method: An Easy way of Achieving Speech. International Journal of Academic Research in Business and Social Sciences, 3(12), 10-13. DOI: https://doi.org/10.6007/IJARBSS/v3-i12/412

Maspalah. (2015). Metode Audio-lingual dalam Pembelajaran Bahasa Arab untuk Meningkatkan Kemampuan Berbicara. Jurnal Pendidikan Bahasa Dan Sastra UPI, 15(1), 68-78.

https://media.neliti.com/media/publications/119433-ID-metode-audiolingual-dalam-pembelajaran-b.pdf

Mei, S. Y., Ju, S. Y., \& Mohd, A. B. (2017). Cooperative Learning Strategy in Teaching Arabic for Non Native Speakers. European Journal of Social Sciences Education and Research, 11(2), 262-267. DOI: https://doi.org/10.26417/ejser.v11i2.p261-266

Mei, Y. (2018). Comments on the Audio-lingual Method. International Journal of Arts and Commerce, 74$), 47-53$. https://ijac.org.uk/images/frontImages/gallery/Vol.7No.4/5.47-53.pdf

Meyad, N. A., Roslan, S., Abdullah, M. C., \& HajiMaming, P. (2014). The Effect of Differentiated Learning Method in Teaching Arabic Language on Students' Motivation. Journal of Social Science Research, 5(8), 671-678. DOI: https://doi.org/10.24297/jssr.v5i1.6651

Nikmah, K. (2020). Interrogative Sentence: A Contrastive Study of Arabic and Indonesian. Izdihar: Journal of Arabic Language Teaching, Linguistics, and Literature, 2(3), 183-200. DOI: https://doi.org/10.22219/jiz.v2i3.10148

Pace, F. A. (1972). The Bases in Pragmatism of the Audio-Lingual Method of Teaching Modern Languages. Michigan: University Microfilms.

Rachmawati, M., Nugrahaeni, F., \& Mauludiyah, L. (2020). Improving Arabic 
Speaking Skill through Mind Mapping Strategy. Izdihar: Journal of Arabic Language Teaching, Linguistics, and Literature, 3(1), 31-44. DOI: https://doi.org/10.22219/jiz.v3i1.10967

Rahmawati, N. (2019). Pengaruh Media Audio Visual terhadap Pemahaman Maharoh Istima' Bahasa Arab. IQ (I/mu Al-Qur'an): Jurnal Pendidikan Islam, 2(02), 217-231. DOI: https://doi.org/10.37542/iq.v2i02.34

Ramadhah, H. I., Ghabban, M. I., 'Umsyah, K. H. A., Isma'ili, Y., 'Ali, S., AlQawasimiyyah, W., Syu'ban, M., Al-Syaikh, M. A., Bu'atur, T., Mukhtari, F., \& Bulbake, J. (2018). Ma'ayir Maharat al-Lughah al-'Arabiyyah Linnathiqina bi Ghairiha (Issue 1).

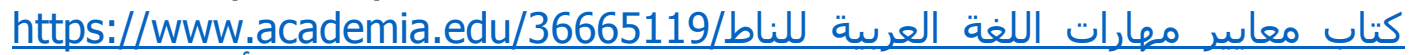
قين يغرها أبحاث محكمة

Ramadhan, H. I. (2017). Ta'lim al-'Arabiyyah li Ghayr al-Nathiqina biha Ru'yah Istisyrafiyyah (Issue 1). Mansyurat al-Muntadi al-'Araby al-Turkey.

Ritonga, M., Alrasi, F., \& Bambang. (2018). Dirasah Tahliliyah 'an Ahammiyah Ma'rifah al-Tashrif fi Fahmi al-Lughah al-'Arabiyyah. Arabiyatuna: Jurnal Bahasa Arab, 2(1), 23-34. DOI: http://dx.doi.org/10.29240/jba.v2i1.333

Rozi, F. (2017). Musykilat Ta'lim al-Mufradat al-'Arabiyyah Linnathiqina bi Ghairiha wa Iqtirahat Lihalliha. Jurnal Ummul Qura, 9(1), 42-55. http://ejournal.kopertais4.or.id/pantura/index.php/qura/article/view/3038

Samah, R., Puteh-behak, F., Saad, N. S. M., Ali, S. M., Darmi, R., \& Harun, H. (2016). Effective Methods in Learning Arabic Language as a Foreign Language. Mediterranean Journal of Social Science, 73), 349-355. DOI: https://doi.org/10.5901/mjss.2016.v7n3p349

Sartika, F., \& Ritonga, M. (2020). Ta'tsir Isti'mal al-Wasa'il al-Sam'iyyah alBashariyyah "Ala Nataij Ta'lim Mufradat al-Lughah al-'Arabiyyah Lilfashl alRabi" fi al-Madrasah al-Ibtida'iyah al-Islamiyyah al-Hukumiyyah Parambahan Lambasi Payakumbuh. Alfazuna, 4(2), 144-154. DOI: https://doi.org/10.15642/alfazuna.v4i02.592

Sbai, M. A., \& Ouakrime, M. (2016). Teaching the Speaking Skill through The Audio-lingual Method.

https://www.academia.edu/21774215/Teaching the Speaking Skill throug $\underline{\mathrm{h} \text { The Audio lingual Method }}$

Susanti, E., Ritonga, M., \& Bambang, B. (2020). Pengaruh Penggunaan Media Powerpoint Terhadap Minat Belajar Bahasa Arab Siswa. Arabiyatuna: Jurnal Bahasa Arab, 4(1), 179-191. DOI: https://doi.org/10.29240/jba.v4i1.1406

Syakur, N. (2010). Revolusi Metodologi Pembelajaran Bahasa Arab dari Pendekatan Komunikatif ke Komunikatif Kambiun. Yogyakarta: Pedagogia.

Taufiq, A. (2018). Dafi'iyah Istikhdam at-Ta'allum at-Ta'awuni Litanmiyyah Ta'lim Maharah al-Kalam. Jurnal Izdihar: Journal of Arabic Language 
Teaching, Linguistics, and Literature, 1(1), 79-104. DOI: https://doi.org/10.22219/izdihar.v1i1.6564

Thu'aimah, R. A. (2004). al-Maharat al-Lughawiyyah Mustawiyatuha Tadrisuha Shu'ubatuha (Issue 1). Cairo: Dar al-Fikr al-'Araby.

Wahab, M. A. (2015). Pembelajaran Bahasa Arab di Era Posmetode. Arabiyat: Jurnal Pendidikan Bahasa Arab Dan Kebahasaaraban [Online], 2(1), 59-74. DOI: https://doi.org/10.15408/a.v2i1.1519

Wargadinata, W., Maimunah, I., Febriani, S. R., \& Humaira, L. (2020). Mediated Arabic Language Learning for Arabic Students of Higher Education in COVID-19 Situation. Izdihar: Journal of Arabic Language Teaching, Linguistics, and Literature, 3(1), 59-78. DOI:

https://doi.org/10.22219/jiz.v3i1.11862

Zahro, U. C., Amalia, S. R., \& Amin, N. F. (2020). The Effectiveness of Direct Method in Arabic Language Learning. Jurnal Al Bayan; Jurnal Jurusan Pendidikan Arab, 12(1), 149-164. DOI: https://doi.org/10.24042/albayan.v12i1.5775 